\title{
Antimicrobial Efficacy of Chlorhexidine and Licorice Mouthwashes in Children
}

\section{Çocuklarda Meyan Kökü ve Klorheksidin Içerikli Gargaraların Antimikrobiyal Etkinliğinin Değerlendirilmesi}

\author{
(1) Fatih Öznurhan ${ }^{1}$, (1) Burak Buldur ${ }^{1}$, (1) Özgül Cart ${ }^{1}$, (1) Uğur Tutar ${ }^{2}$, (1) Cem Çelik ${ }^{3}$, (1) Ceylan Hepokur ${ }^{4}$ \\ ${ }^{1}$ Cumhuriyet University Faculty of Dentistry, Department of Pediatric Dentistry, Sivas, Turkey \\ ${ }^{2}$ Cumhuriyet University Faculty of Health Sciences, Department of Nutrition and Dietetics, Sivas, Turkey \\ ${ }^{3}$ Cumhuriyet University Faculty of Medicine, Department of Medical Microbiology, Sivas, Turkey \\ ${ }^{4}$ Cumhuriyet University Faculty of Pharmacy, Department of Biochemistry, Sivas, Turkey
}

Keywords

Licorice, mouthwash, chlorhexidine, children, antibacterial

\begin{abstract}
Anahtar Kelimeler
Meyan Kökü, gargara, klorheksidin, çocuk, antibakteriyel
\end{abstract}

Received/Geliş Tarihi : 10.01.2018

Accepted/Kabul Tarihi : 23.05.2018

doi:10.4274/meandros.galenos.2018.79663

Address for Correspondence/Yazışma Adresi: Fatih Öznurhan MD,

Cumhuriyet University Faculty of Dentistry, Department of Pediatric Dentistry, Sivas, Turkey Phone : +90 5326338781

E-mail : fatihozn@hotmail.com

ORCID ID: orcid.org/0000-0002-7797-0932

(C) Meandros Medical and Dental Journal, Published by Galenos Publishing House.

This is article distributed under the terms of the Creative Commons Attribution NonCommercial 4.0 International Licence (CC BY-NC 4.0).

\begin{abstract}
Objective: The aim of this in vivo study is to evaluate the effectiveness of a simple herbal caries-prevention protocol for reducing salivary Streptococcus mutans levels in children.

Materials and Methods: A total of 90 individuals were recruited randomly divided into three groups $(n=30)$. Mouthwashes including chlorhexidine $(\mathrm{CHX})$, licorice and saline were used as tested antimicrobial agents, and saliva samples were collected before rinsing, at the end of $5 \mathrm{~min}$ (T1) and $60 \mathrm{~min}$ (T2) following rinsing, and the differences were calculated within 5-60 min (T3). Plaques were evaluated following incubation, and counts of the growing colonies were performed in colony forming units (CFU)/mL. Decreases in CFU were calculated in ratio for statistical analysis. Data were analyzed with Kruskal-Wallis, Mann-Whitney U, Friedman and Wilcoxon signed rank tests by Bonferroni correction, using a 0.05 of significance level.

Results: CHX caused significantly different decreases for T1 and T2 $(p<0.05)$, but, there were no significant differences between $\mathrm{CHX}$ and licorice for T3 ( $p>0.05)$.

Conclusion: Licorice might be a useful agent for dental procedures and further studies are needed to learn more about the dose of licorice, the ratio of glycyrrhizin and the duration of dental therapy.
\end{abstract}

Öz

Amaç: Bu in vivo çalışmanın amacı, çocuklarda tükürük Streptococcus mutans (SM) düzeylerini azaltmaya yönelik basit bir bitkisel çürük önleme protokolünün etkinliğini değerlendirmektir.

Gereç ve Yöntemler: Yapılan bu çalışmada Klorheksidin (CHX), meyan kökü ve serum fizyolojik kullanılmıştır. Toplam 90 hasta, her bir grup için 30 kişi olacak şekilde rastgele 3 gruba ayrıldı. Gargara öncesi, gargaradan $5 \mathrm{dk}$ sonra ve gargaradan 1 saat sonrasında tükürük örnekleri toplanmıştır. Değerlendirmeler gargara sonrası $5 \mathrm{dk}$ (T1), 1 saat sonra (T2) ve aradaki farklılıkları tespit amacıyla 5-60 dk (T3) olarak hesaplanmıştır. Ekimi yapılan örneklerin enkübasyon süresi sonunda plaklar değerlendirmeye alınarak üreyen kolonilerin colony forming Unit/mL (CFU mL-1) olarak sayımları yapılmıştır. CFU değerlerindeki azalmalar istatistiksel olarak analiz edildi. Elde edilen verilerin değerlendirilmesinde Kruskall-Wallis, Mann-Whitney $\mathrm{U}$ and Bonferroni düzeltmeli Friedman, Wilcoxon işaret ve testleri ile yapıldı ve yanılma düzeyi 0,05 olarak alındı.

Bulgular: $\mathrm{CHX}, \mathrm{T} 1$ ve T2 zamanları içerisinde istatistiksel olarak anlamlı düşüşler gösterirken $(p<0,05)$, T3 grubunda $\mathrm{CHX}$ ve meyan kökü grubunda istatistiksel olarak anlamlı bir farklılık görülmedi ( $p>0,05)$.

Sonuç: Meyan kökü dental işlemlerde kullanılabilecek yararlı bir ajan olabilir ve meyan kökü oranının, içerisindeki glisirizik asit yüzdesinin ve tedavinin süresi ile ilgili daha ileri çalışmaların yapılması gerekmektedir. 


\section{Introduction}

Dental caries is a multifactorial, infectious and most common disease, caused by a specific group of cariogenic bacteria $(1,2)$. World Health Organization estimated that 5 billion people of the world's 6.5 billion population are affected by dental caries (3). Dental caries has been prevalent and costly disease in Turkey as well, particularly during childhood. In 2004, caries prevalence was $69.8 \%$ (4) and in 2011, it was $46.9 \%$ in Turkey (5). Clinical studies indicated that oral colonization of Streptococcus mutans (SM) promotes dental caries development in humans $(6,7)$. SM plays an important role in the dental caries by acid production. SM show adherence in retentive areas of the tooth structure, especially pit and fissures (7). In the presence of sucrose, SM efficiently enhance biofilm biomass and promote ecological shifts that lead to emergence of acidogenic and aciduric organisms (8).

People can avoid from dental caries with regular tooth brushing, favorable dietary habits and regular dental check-up (9). Tooth brushing and flossing might be effective to prevent caries. However, in some instances mechanical methods need to be combined with chemoprophylactic agents to prevent tooth caries (10). Various antibacterial agents have been produced and tested to decrease the number of cariogenic bacteria, to reduce acid production and to prevent biofilm formation (2). One such successful chemotherapeutic agent is chlorhexidine (CHX). $\mathrm{CHX}$ has antimicrobial activity against SM and also demonstrates antiplaque and antigingivitis properties $(11,12)$. On the other hand, the use of $\mathrm{CHX}$ has some side effects such as staining, altered taste sensation, vomiting, increased risk of caries due to fermentation and alcohol content, development of resistant bacterial strains or oral cancers $(13,14)$.

Innovations and recent research in dentistry witnessed a new herbal material named licorice. Glycyrrhiza glabra, known as Licorice root, is one such medicinal plant that has been used since ancient times to relieve coughs, sore throats, gastric inflammation as a traditional herbal remedy (15). It has been used as a sweetener in food and drug industry and Food and Drug Administration listed licorice in generally regarded as safe (1).

Licorice root compounds with their anti-adherence, antimicrobial and anti-inflammatory effects may help treating oral diseases including tooth decay $(16,17)$. Licorice is 50 times sweeter than sucrose and acting as a gustatory stimulus, it can increase salivary flow thus they can provide an anti-caries effect (18).

In recent years, a few studies regarding anticariogenic properties of Glycyrrhiza glabra has been published. Chaiya et al. (19) have demonstrated that Glycyrrhiza glabrahas inhibited the growth of SM as well as the adherence ability of the bacteria. Jain et al. (15) have showed antimicrobial and cariostatic efficacy of liquorice extracts and recommend that liquorice can be used as a preventive regimen in pediatric dental practice. Hu et al. (20) and Peters et al. (1) have demonstrated that licorice containing lollipop led to reduction in salivary SM in their studies.

The purpose of this in vivo study was to evaluate the effectiveness of a simple herbal caries-prevention protocol aimed at reducing salivary SM levels in children.

\section{Materials and Methods}

Ethical approval for this study was obtained from the Cumhuriyet University Clinical Research Ethic Committee (2014-02/15) and the study was conducted at the Cumhuriyet University Faculty of Dentistry, Department of Pediatric Dentistry, Sivas, Turkey.

\section{Sample Distribution}

In this study, with an $\alpha=0.05, \beta=0.20$ and (1$\beta)=0.90$, a total of 90 individuals [ 48 girls $(53.3 \%, 42$ boys $(46.7 \%)$ ] were included in this study and the power of the test was $p=0.8099$.

\section{Licorice Root Extract Solution Preparation}

Two hundred $\mathrm{mg}$ of licorice was weighed and mixed with a $20 \mathrm{~m}$ of a solution composed of a mixture of distilled water and ethyl alcohol at a rate of $70: 30$ at $60^{\circ} \mathrm{C}$ for 25 minutes. The mixed solution was centrifuged at $3000 \mathrm{rpm}$ for 10 minutes and the extract was separated. Finally, the supernatant was filtered from a membrane filter and was prepared for use. $75 \mathrm{~mL}$ rinse solution was freshly prepared to be used in patients in $15 \mathrm{~mL}$ cups for single use and prepared again when it finished.

\section{Measurements}

The measurement is planned through the following method. The subjects were selected using simple lottery method from patients who are aged 10-13 years (mean age: 11.33 ) and have a clinical picture of 
simple gingivitis. The same procedures were followed for all patients. The patients who have unknown allergies or idiopathic allergies were excluded from the study.

Saliva samples were collected before gargling, at the end of $5 \mathrm{~m}$ (T1), $1 \mathrm{~h}$ (T2) and was transferred to laboratory as soon as possible. The differences were calculated within 5-60 m (T3) (Figure 1).

CHX group; Saliva samples were obtained from all patients (baseline) and then patients rinsed their mouth with $\mathrm{CHX}(0.2 \%$ of $\mathrm{CHX}$ solution, klorhex, drogsan, Ankara, Turkey). After 5 min, a new saliva sample was taken to count SM and the last saliva sample was taken at the end of $1 \mathrm{~h}$.

LICORICE group; Saliva samples were obtained from all patients (baseline) and then, the patients rinsed their mouth with freshly prepared licorice (in $15 \mathrm{~mL}$ cups for $1 \mathrm{~min}$ ) and then two saliva samples were obtained at the end of $5 \mathrm{~min}$ and $1 \mathrm{~h}$.

SALINE group; Saliva samples were obtained from all patients (baseline) and then, after rinsing their mouth with saline, the saliva samples were taken at the end of $5 \mathrm{~min}$ and $1 \mathrm{~h}$ to see any decrease in SM count.

After collecting saliva samples, the samples were sent to microbiology laboratory immediately.

\section{Streptococcus Mutans Count}

A saliva sample of $0.01 \mathrm{~mL}$ was obtained and added to a physiologic serum solution of $9.99 \mathrm{~mL}$. A $0.01 \mathrm{~mL}$ of the obtained suspension was taken using a sterile plastic loop and was cultured in Difco ${ }^{\mathrm{TM}}$ Mitis Salivarius Agar (Becton, Dickinson and Company, Sparks, MD, USA). The agars were incubated for 24-48 $\mathrm{h}$ in an environment with $5 \% \mathrm{CO}_{2}$ at $36.5^{\circ} \mathrm{C}$. Plaques were evaluated following incubation and counts of the growing colonies were performed in colony forming ünits $/ \mathrm{mL}^{-1}$ (CFU mL ${ }^{-1}$ ). Elevated colonies that grew in the plaques that were faded blue in color and had a granular ground-glass appearance were accepted as
SM. Colonies evaluated to be SM in the agars were confirmed using Microflex LT MALDI-TOF MS (Bruker Daltonics, Bremen, Germany) and BD Phoenix 100 system (Becton Dickinson Diagnostic Instrument Systems, Sparks, MD, USA) and Streptococcus definition panels (BD Phoenix SMIC/ID-11 Becton Dickinson, Sparks, MD, USA).

\section{Statistical Analysis}

After counting the SM colonies, the data were enrolled and the percentages were calculated by the ratio of the decreases in SM count. The data was enrolled with SPSS 17 . The compliance of normal distribution of data was performed by Shapiro Wilk test. Kruskal-Wallis Mann-Whitney $U$ test was performed with Bonferroni correction because of non-compliance with a normal distribution. Variations by time were performed with Friedman Wilcoxon signed-rank test by Bonferroni correction. A $p$ value of 0.05 was referred statistically different.

\section{Results}

Table 1 shows the minimum, maximum and median CFU of the groups. For the first 5 min (T1), CHX caused $100 \%$ decrease in some samples and CHX showed significantly different decreases in SM count when compared with the other groups. $\mathrm{CHX}$ and licorice showed $100 \%$ decrease in some samples in T2. CHX and Licorice showed significantly higher decreases in binary comparisons of the groups (Table 2). $\mathrm{CHX}$ showed significantly different decreases in $\mathrm{T} 1$ and $\mathrm{T} 2$ group but there were no significant differences in T3 between CHX and Licorice ( $p>0.05$ ). Decreases were seen in all samples of $\mathrm{CHX}$ and Licorice groups (Figure 2). The rankings of reducing of the number of bacteria colonies were $\mathrm{CHX}>$ Licorice $>$ Saline in $\mathrm{T} 1$ and $\mathrm{T} 2$ but there were no significant differences in $\mathrm{T} 3$ between $\mathrm{CHX}$ and Licorice ( $\mathrm{p}>0.05$ ). Licorice and $\mathrm{CHX}$ decreased SM count $100 \%$ in some samples (Figure 3 ).

\begin{tabular}{|c|c|c|c|c|c|c|c|c|c|}
\hline \multirow{2}{*}{$\begin{array}{l}\text { Times } \\
\text { Groups }\end{array}$} & \multicolumn{3}{|l|}{ T1 } & \multicolumn{3}{|l|}{ T2 } & \multicolumn{3}{|l|}{ T3 } \\
\hline & $\min$ & $\max$ & Mean + SD & Min & $\max$ & Mean + SD & $\min$ & $\max$ & Mean + SD \\
\hline SF & 5.26 & 44.82 & $23.14+11.27$ & 7.69 & 37.93 & $20.08+10.71$ & 0 & 42.85 & $11.03+10.27$ \\
\hline Licorice & 7.31 & 67.30 & $39.70+16.18$ & 37.50 & 100 & $69.18+14.88$ & 5.08 & 60 & $29.47+17.01$ \\
\hline $\mathrm{CHX}$ & 18.75 & 100 & $69.26+20.86$ & 53.84 & 100 & $89.33+12.88$ & 0 & 57.81 & $20.87+12.92$ \\
\hline
\end{tabular}




\begin{tabular}{|c|c|c|c|c|c|c|c|c|c|}
\hline & \multicolumn{3}{|l|}{ Saline } & \multicolumn{3}{|c|}{ Licorice } & \multicolumn{3}{|l|}{ CHX } \\
\hline & T1 & T2 & T3 & $\mathrm{T} 1$ & T2 & T3 & $\mathrm{T} 1$ & T2 & T3 \\
\hline Saline & - & - & - & 0.001 & 0.000 & 0.000 & 0.000 & 0.000 & 0.003 \\
\hline Licorice & 0.001 & 0.000 & 0.000 & - & - & - & 0.000 & 0.000 & $0.167^{*}$ \\
\hline CHX & 0.000 & 0.000 & 0.003 & 0.000 & 0.000 & $0.167^{*}$ & - & - & - \\
\hline
\end{tabular}

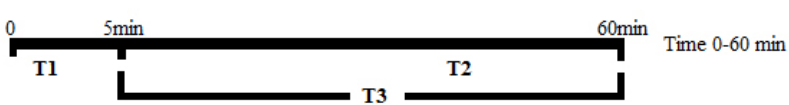

Figure 1. Timing of the groups, T1: 0-5 $\mathrm{min}, \mathrm{T} 2: 0-60 \mathrm{~min}, \mathrm{~T} 3$ : $5-60 \mathrm{~min}$

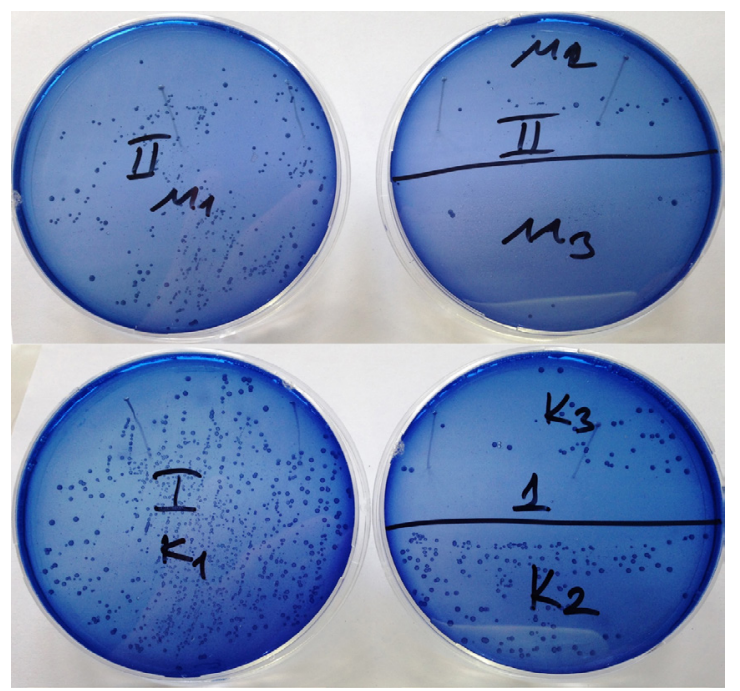

Figure 2. Chlorhexidine ( $\mathrm{CHX})$ and licorice showed decreases in all samples $\left(\mathrm{M}_{1}\right.$ : Licrorice $\mathrm{T} 1, \mathrm{M}_{2}$ : Licorice $\mathrm{T} 2, \mathrm{M}_{3}$ : Licorice $\mathrm{T} 3, \mathrm{~K}_{1}$ : $\mathrm{CHX} \mathrm{T1}, \mathrm{K}_{2}:$ CHX T2, $\mathrm{K}_{3}: \mathrm{CHX}$ T3)
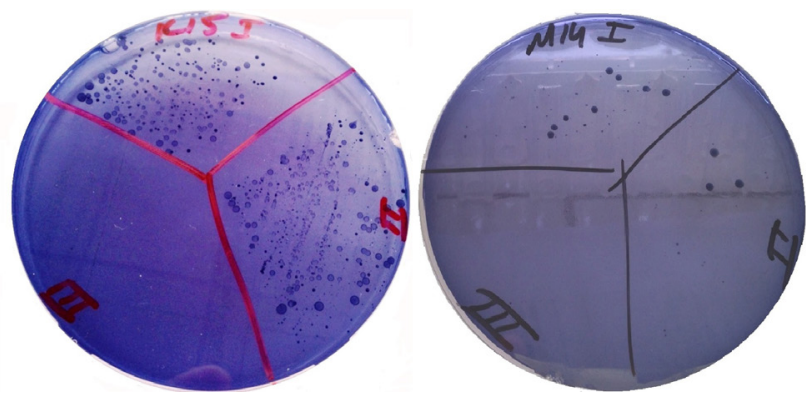

Figure 3. Shows $100 \%$ decreased amount of streptokok mutans $\left[\mathrm{M}_{1}\right.$ : Licorice $\mathrm{T} 1, \mathrm{M}_{2}$ : Licorice $\mathrm{T} 2, \mathrm{M}_{3}$ : Licorice $\mathrm{T} 3, \mathrm{~K}_{1}$ : Chlorhexidine (CHX) T1, $\mathrm{K}_{2}$ : CHX T2, $\mathrm{K}_{3}$ : CHX T3]

\section{Discussion}

The main purpose of dentistry is to help humans to maintain oral health throughout their life (2). The most common dental problems were caused by microorganisms and these microorganisms are responsible in pulpitis, infection mediated necrosis and their extension to the periapical tissue. Removing dental plaque or killing oral bacteria with antibacterials are common anti-microbial strategies to treat dental caries $(21,22)$.

$\mathrm{CHX}$ is used for chemical plaque control and inhibition of bacterial colonization to tooth surfaces. In the oral cavity, $\mathrm{CHX}$ is an effective antibacterial agent and has effect on a wide range of microorganisms. Being effective on some SM species, CHX is used to prevent and reduce carious lesions. $\mathrm{CHX}$ reacts directly with the surface of microbial cell, destroys the cell membrane integrity, penetrates the cell, and precipitates the cytoplasm leading to cell death $(15,23)$. CHX or $\mathrm{CHX}$ containing oral health products has the strongest antimicrobial action against SM.

As it is shown in several clinical studies that $\mathrm{CHX}$ gluconate is a cationic bisguanide which has a broadspectrum antimicrobial action and has effectiveness in decreasing the formation of dental biofilm (plaque) and gingivitis $(24,25)$. However, $\mathrm{CHX}$ has some side effects likemain bitter taste and the formation of extrinsic stains on the teeth and tongue, increased risk of caries due to fermentation and alcohol content, discoloration, altered taste perception, metallic taste, staining of teeth and cytotoxic effects on cells $(15,23)$. All these disadvantages have led current research to more natural and biocompatible agents like herbal medicines (26).

History of herbal medicines usage be rooted from ancient civilization and have been used for many years where their role as a primary source of medicine has been evident. In developing countries herbal 
medicines are still the mainstay of about $75-80 \%$ of the population for primary health care because of better cultural acceptability, better compatibility with human body, and fewer side effects. Hence, studies are being carried out to discover new alternate plantbased bioactive compounds which will be safer, easily available, and substitute standard pharmaceutical remedies $(21-23,27)$.

Antimicrobial activity of licorice was shown in many studies $(28,29)$. It is used for many purposes like antibacterial agent, for ulcerous lesions, mouth wash, endodontic infections, and periodontitis. It demonstrates anti-inflammatory, antimicrobial, anticarcinogenic and hepatoprotective effects $(23,27,28,30-32)$. One of the aims of using licorice is to reduce the bacteria colonies that lead dental caries and, for this purpose, licorice was added into lollipop, gargling solutions and gels.

In this study, licorice was used as gargling solution. There are two forms of licorice gargling solution. One is aqueous licorice form and the other is alcoholic licorice form. Ajagannanavar et al. (21) declared that alcoholic root extract of licorice was superior to aqueous form and CHX. Sedighinia et al. (27) declared that the ethanolic extract of Glycyrrhiza glabra had promising macrophage inhibitory cytokine value against all oral bacteria, especially $S$. mutans, $A$. viscosus, and E. faecalis. Ahn et al. (23) found that three purified compounds that were isolated from ethanol-extracted licorice root, were less cytotoxic to normal human gingival fibroblast cells than $\mathrm{CHX}$. Jain et al. (15) concluded that alcohol was a better solvent than water and that the reduction in colony counts of ethanolic licorice group was more significant than the control groups. In line with the results of these studies, alcoholic form of licorice was preferred in this study.

CHX, has been considered to be the gold standard of oral therapies due to its prolonged broad spectrum antimicrobial property, but is accompanied by altered taste perception, metallic taste, and staining of teeth. $\mathrm{CHX}$ also possesses the unique property of substantivity, pertaining to which it has slow, sustained release in the oral cavity and hence, prolonged action $(15,24,33)$. CHX was one of the mouthwashes used in this study. CHX showed more decrease in SM count than the other mouthwashes in T1 and T2 and the decreases were statistically different. However in T3, licorice showed $30 \%$ and CHX showed $19.37 \%$ decrease, though there were no significant differences between both groups. This has led to a conclusion that licorice showed its effect in a long-time period. The authors declared that one of the limitations of this study was that the study was completed in one hour and long-term follow up studies are needed to support this conclusion.

In some samples, both licorice and $\mathrm{CHX}$ decreased SM count $100 \%$ and this result indicated that the licorice mouthwash is a dose dependent material which shows its effectiveness by containing glycyrrhizin. Glycyrrhizin is the most important ingredient of licorice which might be in a high concentration and provide the antimicrobial effect of licorice $(15,28)$. The high concentration of glycyrrhizin $(5 \%, 10 \%)$ slightly inhibited bacterial growth, but completely abolished plaque formation (34). Soderling et al. (28) declared that the liquorice extract inhibited acid production effectively in vivo with concentrations ranging from 2.5 to $10 \%$. Glycyrrhiza glabra extract containing 7-7.5\% glycyrrhizin was found advantageous in terms of cytotoxicity because $87 \%$ of periodontal ligament fibroblasts were alive after $48 \mathrm{~h}$ (30). Another limitation of this study is that the ratio of glycyrrhizin could have been calculated initially, but being an in vivo study, could give the authors more opinions for further studies.

\section{Study Limitation}

There are some disadvantages of $\mathrm{CHX}$ and this study shows herbal products can be alternatives to this kind of products.

The importance of herbal products are increasing and this study shows licorice can be an alternative to $\mathrm{CHX}$.

If effective dose of active substance of licorice is detected and prepared as a gargling solution, the patients will survive from side effects of $\mathrm{CHX}$.

\section{Conclusion}

The results of this study indicated that licorice might be a useful tool for dental procedures and further studies are needed to learn more about the dose of licorice, the ratio of glycyrrhizin and the duration of dental therapy. 


\section{Ethics}

Ethics Committee Approval: Ethical approval for this study was obtained from the Cumhuriyet University Clinical Research Ethic Committee (201402/15).

Informed Consent: Informed consent forms were taken both from patients and parents.

Peer-review: Externally peer-reviewed.

Authorship Contributions

Surgical and Medical Practices: F.Ö., B.B., Ö.C., Concept: F.Ö., C.H., Design: F.Ö., U.T., C.C., C.H., Data Collection or Processing: F.Ö., B.B., Ö.C., Analysis or Interpretation: F.Ö., B.B., Literature Search: F.Ö., Ö.C., B.B., Writing: F.Ö.

Financial Support and Sponsorship: The study was supported by CUBAP.

Conflict of interest: The authors declare that they have no conflict of interest. This study was supported.

\section{References}

1. Peters MC, Tallman JA, Braun TM, Jacobson JJ. Clinical reduction of $\mathrm{S}$. mutans in pre-school children using a novel liquorice root extract lollipop: a pilot study. Eur Arch Paediatr Dent 2010; 11: 274-8.

2. Sajjan PG, Nagesh L, Sajjanar M, Reddy SK, Venktesh UG. Comparative evaluation of chlorhexidine varnish and fluoride varnish on plaque Streptococcus mutans count--an in vivo study. Int J Dent Hyg 2013; 11: 191-7.

3. Rigonatto DD, Antunes JL, Frazao P. Dental caries experience in Indians of the Upper Xingu, Brazil. Rev Inst Med Trop Sao Paulo 2001; 43: 93-8.

4. Gokalp SG, Dogan BG, Tekcicek MT, Berberoglu A, Unluer S. National survey of oral health status of children and adults in Turkey. Community Dent Health 2010; 27: 12-7.

5. Ozer S, Sen Tunc E, Bayrak S, Egilmez T. Evaluation of certain risk factors for early childhood caries in Samsun, Turkey. Eur J Paediatr Dent 2011; 12: 103-6.

6. Banas JA. Virulence properties of Streptococcus mutans. Front Biosci 2004; 9: 1267-77.

7. Bowen WH, Koo H. Biology of Streptococcus mutans-derived glucosyltransferases: role in extracellular matrix formation of cariogenic biofilms. Caries Res 2011; 45: 69-86.

8. Lemos JA, Burne RA. A model of efficiency: stress tolerance by Streptococcus mutans. Microbiology 2008; 154: 3247-55.

9. Gao X, Lo EC, McGrath C, Ho SM. Innovative interventions to promote positive dental health behaviors and prevent dental caries in preschool children: study protocol for a randomized controlled trial. Trials 2013; 14: 118.

10. Agarwal P, Nagesh L. Comparative evaluation of efficacy of $0.2 \%$ Chlorhexidine, Listerine and Tulsi extract mouth rinses on salivary Streptococcus mutans count of high school children-RCT. Contemp Clin Trials 2011; 32: 802-8.

11. Schaeken MJ, De Jong MH, Franken HC, Van der Hoeven JS. Effects of highly concentrated stannous fluoride and chlorhexidine regimes on human dental plaque flora. J Dent Res 1986; 65: $57-$ 61.

12. Emilson CG. Potential efficacy of chlorhexidine against mutans streptococci and human dental caries. J Dent Res 1994; 73: 68291.

13. Park KM, You JS, Lee HY, Baek NI, Hwang JK. Kuwanon G. an antibacterial agent from the root bark of Morus alba against oral pathogens. J Ethnopharmacol 2003; 84: 181-5.

14. Chung JY, Choo JH, Lee MH, Hwang JK. Anticariogenic activity of macelignan isolated from Myristica fragrans (nutmeg) against Streptococcus mutans. Phytomedicine 2006; 13: 261-6.

15. Jain E, Pandey RK, Khanna R. Liquorice root extracts as potent cariostatic agents in pediatric practice. J Indian Soc Pedod Prev Dent 2013; 31: 146-52.

16. Rackova L, Jancinova V, Petrikova M, Drabikova $K$, Nosal R, Stefek $M$, et al. Mechanism of anti-inflammatory action of liquorice extract and glycyrrhizin. Nat Prod Res 2007; 21: 1234-41.

17. Gupta VK, Fatima A, Faridi U, Negi AS, Shanker K, Kumar JK, et al. Antimicrobial potential of Glycyrrhiza glabra roots. J Ethnopharmacol 2008; 116: 377-80.

18. Messier C, Epifano F, Genovese S, Grenier D. Licorice and its potential beneficial effects in common oro-dental diseases. Oral Dis 2012; 18: 32-9.

19. Chaiya A, Saraya S, Chuakul W, Temsiririrkkul R. Screening for Dental Caries: Preventive Activities of Medicinal Plants against Streptococcus mutans. J Pharm Sci 2013; 40: 9-17.

20. $\mathrm{Hu} \mathrm{CH}, \mathrm{He}$ J, Eckert R, Wu XY, Li LN, Tian Y, et al. Development and evaluation of a safe and effective sugar-free herbal lollipop that kills cavity-causing bacteria. Int J Oral Sci 2011; 3: 13-20.

21. Ajagannanavar SL, Battur H, Shamarao S, Sivakumar V, Patil PU, Shanavas P. Effect of aqueous and alcoholic licorice (glycyrrhiza glabra) root extract against streptococcus mutans and lactobacillus acidophilus in comparison to chlorhexidine: an in vitro study. J Int Oral Health 2014; 6: 29-34.

22. Sharma H, Yunus GY, Mohapatra AK, Kulshrestha R, Agrawal $R$, Kalra M. Antimicrobial efficacy of three medicinal plants Glycyrrhiza glabra, Ficus religiosa, and Plantago major on inhibiting primary plaque colonizers and periodontal pathogens: An in vitro study. Indian J Dent Res 2016; 27: 200-4.

23. Ahn SJ, Park SN, Lee YJ, Cho EJ, Lim YK, Li XM, et al. In vitro antimicrobial activities of 1-methoxyficifolinol, licorisoflavan $A$, and 6,8-diprenylgenistein against Streptococcus mutans. Caries Res 2015; 49: 78-89.

24. Prasanth M. Antimicrobial efficacy of different toothpastes and mouthrinses: an in vitro study. Dent Res J (Isfahan) 2011; 8: 8594.

25. Lorenz K, Bruhn G, Heumann C, Netuschil L, Brecx M, Hoffmann T. Effect of two new chlorhexidine mouthrinses on the development of dental plaque, gingivitis, and discolouration. A randomized, investigator-blind, placebo-controlled, 3-week experimental gingivitis study. J Clin Periodontol 2006; 33: 561-7. 
26. Parwani SR, Parwani RN, Chitnis PJ, Dadlani HP, Prasad SV. Comparative evaluation of anti-plaque efficacy of herbal and $0.2 \%$ chlorhexidine gluconate mouthwash in a 4-day plaque regrowth study. J Indian Soc Periodontol 2013; 17: 72-7.

27. Sedighinia F, Safipour Afshar A, Soleimanpour S, Zarif R, Asili J, Ghazvini K. Antibacterial activity of Glycyrrhiza glabra against oral pathogens: an in vitro study. Avicenna J Phytomed 2012; 2: 118-24.

28. Soderling E, Karjalainen S, Lille M, Maukonen J, Saarela M, Autio $\mathrm{K}$. The effect of liquorice extract-containing starch gel on the amount and microbial composition of plaque. Clin Oral Investig 2006; 10: 108-13.

29. Mohire NC, Yadav AV: Chitosan-based polyherbal toothpaste: as novel oral hygiene product. Indian J Dent Res 2010; 21: 380-4.

30. Guldas HE, Kececi AD, Cetin ES, Ozturk T, Kaya BU. Evaluation of antimicrobial efficacy of cetrimide and Glycyrrhiza glabra L. extract against Enterococcus faecalis biofilm grown on dentin discs in comparison with NaOCl. Dent Mater J 2016; 35: 721-7.
31. Almaz ME, Sonmez IS, Okte Z, Oba AA. Efficacy of a sugar-free herbal lollipop for reducing salivary Streptococcus mutans levels: a randomized controlled trial. Clin Oral Investig 2017; 21: 839-45.

32. Ahn SJ, Cho EJ, Kim HJ, Park SN, Lim YK, Kook JK. The antimicrobial effects of deglycyrrhizinated licorice root extract on Streptococcus mutans UA159 in both planktonic and biofilm cultures. Anaerobe 2012; 18: 590-6.

33. Akca AE, Akca G, Topcu FT, Macit E, Pikdoken L, Ozgen IS. The Comparative Evaluation of the Antimicrobial Effect of Propolis with Chlorhexidine against Oral Pathogens: An In Vitro Study. Biomed Res Int 2016; 2016: 3627463.

34. Segal R, Pisanty S, Wormser R, Azaz E, Sela MN. Anticariogenic activity of licorice and glycyrrhizine I: Inhibition of in vitro plaque formation by Streptococcus mutans. J Pharm Sci 1985; 74: 7981. 